\title{
Fé e política em Kierkegaard, à luz da sua obra "Temor e Tremor"
}

\author{
Orientador: Paulo Fernando Carneiro de Andrade \\ Mestrando: Agnaldo da Silva Vieira \\ Área de Concentração: Teologia Sistemático-Pastoral \\ Linha de Pesquisa: Religião e Modernidade
}

Esta pesquisa analisa a relação entre fé e política no pensamento do teólogo e filósofo dinamarquês Soren Aabye Kierkegaard (1813-1855), tomando como base a sua obra ético-religiosa Temor e Tremor. A fé e a política, representadas pela união entre Igreja e Estado, foram temas amplamente explorados por Kierkegaard, que considerou essa forma de entrelaçamento como uma traição ao verdadeiro cristianismo. Sua crítica à cristandade assumiu um duplo movimento, atingindo Igreja e Estado, trazendo inevitavelmente à luz a necessidade de uma crítica religiosa dessas relações para o amadurecimento e aprofundamento da reflexão cristã. Entendemos que a obra Temor e Tremor apresenta a fé como um "modo existencial de ser no mundo", opondo-se energicamente ao universo cultural, político e religioso do século XIX, encontrado nos círculos de pertencimento social e político do luteranismo dinamarquês. Realizando uma contextualização histórica do protestantismo no século XIX, a pesquisa procura demonstrar a crítica de Kierkegaard à teologia especulativa, concentrando-se em sua singular hermenêutica luterana do cristianismo (a existência cristã "em virtude do absurdo"), que se confrontou com os desdobramentos ético-políticos da filosofia e teologia hegelianas. A partir destes elementos o trabalho procura elucidar a delicada relação entre fé e política no pensamento religioso de Kierkegaard.

Palavras-chave: Kierkegaard. Fé. Política. 